\title{
Lactarius vellereus and L. bertillonii in Fennoscandia and Denmark
}

\author{
ILKKA KYTÖVUORI and MAURI KORHONEN
}

\begin{abstract}
KYTÖVUORI, I. \& KORHONEN, M. 1990: Lactarius vellereus and L. bertillonii in Fennoscandia and Denmark. - Karstenia 30:33-42.

The taxonomic status of Lactarius vellereus (Fr.: Fr.) Fr. and L. bertillonii (Neuh. ex Z. Schaefer) M. Bon as separate species is substantiated, their distribution in Fennoscandia and Denmark is mapped, and their ecology and relationships are discussed. In the northern temperate zone, $L$. vellereus is fairly common in broad-leaved forests in Denmark, southernmost Sweden and westernmost Norway. In the hemiboreal zone, it is rarer and concentrated near the coast. $L$. bertillonii is restricted to broad-leaved or mixed forests in the hemiboreal zone and the southern part of the southern boreal zone. Agaricus vellereus Fr. is neotypified.
\end{abstract}

Key words: Distribution, Fennoscandia, Lactarius bertillonii, Lactarius vellereus, taxonomy

Ilkka Kytövuori, Department of Botany, University of Helsinki, Unioninkatu 44, SF00170 Helsinki, Finland

Mauri Korhonen, Botanical Museum, University of Helsinki, Unioninkatu 44, SF00170 Helsinki, Finland

Although the large and conspicuous milk-caps of the Lactarius vellereus group are well-known to most mycologists, the taxonomy and nomenclature of the group are not very clear. In Europe one (e.g. Neuhoff 1956, Moser 1983), two (e.g. Bon 1987), three (Romagnesi 1980) or four (Schaefer 1979, Bon 1980b) species have been recognized in the group. In addition, several varieties have been described, especially by Blum (1966). In North America, Hesler \& Smith (1979) have recognized the stirps Subvellereus, containing two species with two varieties each. Strid (1987) presented a synopsis of the nomenclature of the $L$. vellereus group from the Fennoscandian point of view.

In Europe various authors have generally used the name $L$. vellereus for the whole complex or for the commonest species in each author's study area. In Finland the name $L$. bertillonii was adopted by Ahti (1976, as L. vellereus var. bertillonii) and Korhonen (1984). During field work in South Sweden in autumn 1985 , I. Kytövuori observed that two species of the $L$. vellereus group occur in Fennoscandia. Since then field work in Finland, Denmark and especially Sweden has been continued and the material of the Fennoscandian herbaria has been revised to clarify the distribution of the species in Fennoscandia (preliminary results published in Korhonen \& Kytövuori 1987).

\section{Material and methods}

Specimens were checked in the following herbaria: BG, C, GB, H, JYV, LD, KUO, O, OULU, PRM, S, TRH, TUR, UPS (the symbols according to Holmgren et al. 1981). One specimen was examined from the private herbarium of Mrs. S. Muskos, Sundsvall.

Microscopical characters were examined with the microscope Leitz Laborlux 12 at magnifications of about 625 and 1560 . Spores, basidia and surface hairs were drawn with the Leitz drawing tube at a magnification of 2000 . Spores were examined, measured (with an ocular micrometer) and drawn from slides showing the surface view of pieces of gills of dried basidiocarps, mounted in Melzer's reagent. Only 
spores in a horizontal position were measured; young, anomalous, very small or gigantic spores were excluded. Length and width were measured from the same spore and the length/width ratios were calculated for individual spores.

Basidia and cystidia were drawn and measured from slides with squashes of gill pieces taken from somewhat younger basidiocarps than in the case of the spores and surface hairs were drawn from slides with squashes of pieces of epicutis, both mounted in Melzer's reagent. In older basidiocarps the cystidia were often somewhat collapsed. If the drying conditions are not satisfactory, the hymenium may be squeezed strongly in drying herbarium specimens, and therefore only the best specimens were used in measuring the basidia.

The microscopical studies and revision of the herbarium material were done by Kytövuori. The illustrations are our own.

\section{Key to species}

1 Latex mild (when separate from flesh), pileus and stipe covered by fairly long and thick hairs, spores subglobose, finely reticulate .................................... 1. L. vellereus

- Latex strongly acrid, hairs shorter and thinner, spores ellipsoid to broadly ellipsoid, ornamentation finer, not reticulate

2. L. bertillonii

\section{Lactarius vellereus (Fr.: Fr.) Fr., Figs. 1-3, 5.}

Lactarius vellereus (Fr.: Fr.) Fr., Epicr. 340. 1838. - Agaricus vellereus Fr., Syst. Mycol. I: 76. 1821. - Neotype (selected here): Sweden, Småland, Femsjö, along the ancient road from "Prästgårdens såg" towards the Flahult road. On bare soil, amongst short grass etc., along a road in coniferous wood. 17.IX.1939 Seth Lundell 3505 (UPS), Lundell \& Nannfeldt, Fungi Exs. Suec. Ups. 2334. 1956.

Illustrations: Bon (1987: 95), Dähncke \& Dăhncke (1980: 522), Korhonen (1984: 71, s.n. L. bertillonii), Marchand (1980: 15), Michael et al. (1983: 131), Neuhoff (1956: Pl. 1), Phillips (1981: 76), Viola (1977: Pl. 57).

Large and robust, most often regular in form. Pileus $10-30(-40) \mathrm{cm}$ wide, convex-depressed to plano-depressed, with margin inrolled when young, outrolling and broadly infundibuliform with age, dry, covered by woolly hairs throughout. The hairs long, somewhat curled, with tips tangled into acute tufts, also present in the oldest basidiocarps. Colour uniformly pure white to pale ochraceous or deeper ochraceous in the centre, in dried basidiocarps most often more deeply ochre. Context thick (10-20 mm at broadest point of lamellae) and firm, burningly acrid, with fairly strong somewhat sweetish odour. Latex white, \pm unchanging, mild or only slightly bitter when separate from the flesh, not at all acrid.
Lamellae adnate, moderately narrow (3-10 $\mathrm{mm}$ at broadest point, the context 1.6-3.5 times as thick at the same point), but broader and thinner than in $L$. bertillonii, subdistant, straight, not or only sparsely forked, whitish, lamellulae numerous.

Stipe most often central, stout, short, $2-7 \mathrm{~cm}$ long, 2-5 cm thick, hard, solid, of even thickness or slightly tapering downwards, dry, hirsute like the pileus, but the hairs usually not tangled into tufts.

Spores $8.5-11.0 \times 7.4-9.3 \mu \mathrm{m}$ (263 spores from 14 ex.), length/width ratio $1.13-1.24$, subglobose, with amyloid ornamentation of very slender broken reticulum up to $0.2 \mu \mathrm{m}$ high, plage inamyloid, fairly wide (Figs. 2, 3).

Basidia $66-81 \times 9.5-11.5 \mu \mathrm{m}$ ( 44 bas. from 4 ex.), 4-spored. Macrocystidia abundant, $50-100 \times 5.5-$ $8.5 \mu \mathrm{m}$ (131 cyst. from 7 ex.), narrowly clavate with rounded apex when young, more pointed with age, imbedded or slightly (up to $25 \mu \mathrm{m}$ ) projecting, with the broadest point in the hymenium. Cheilocystidia abundant, similar to the macrocystidia, but smaller, 30-75 x 5-8 $\mu \mathrm{m}$ (158 cyst. from $7 \mathrm{ex}$.), and more $(15-37 \mu \mathrm{m})$ projecting. Differentiated pseudocystidia not seen.

Pileal hairs long, somewhat curled, thick-walled, at the tip 2.5-5.5 $\mu \mathrm{m}$ thick (324 hairs from $28 \mathrm{ex}$.), only slightly thicker at the base. Cauline hairs similar but somewhat straighter.

\section{Distribution and ecology}

Though the yearly fluctuation may be very wide, Lactarius vellereus seems to be common in the temperate zone in Denmark, in southernmost and southwesternmost Sweden and in westernmost Norway. It occurs in frondose woods, especially in beech woods, where it may sometimes be extremely abundant. It also grows in association with Quercus or Betula or some other deciduous tree species and Pinus sylvestris has often been reported from the places where specimens have been collected.

Farther north in the hemiboreal zone the species soon becomes much rarer (Fig. 1). It occurs along the coast up to the Oslo and Stockholm regions, in Aland and very rarely in the southernmost part of the Finnish continent. In the interior of South Sweden it seems to be rare and lacking in large areas.

The northernmost occurrences of $L$. vellereus are known from the southern part of the southern boreal zone, close to the coast, near Helsinki in Finland, near Sundsvall in Sweden and in southern Nordland in western Norway. At the northernmost localities it grows in association with Betula. 


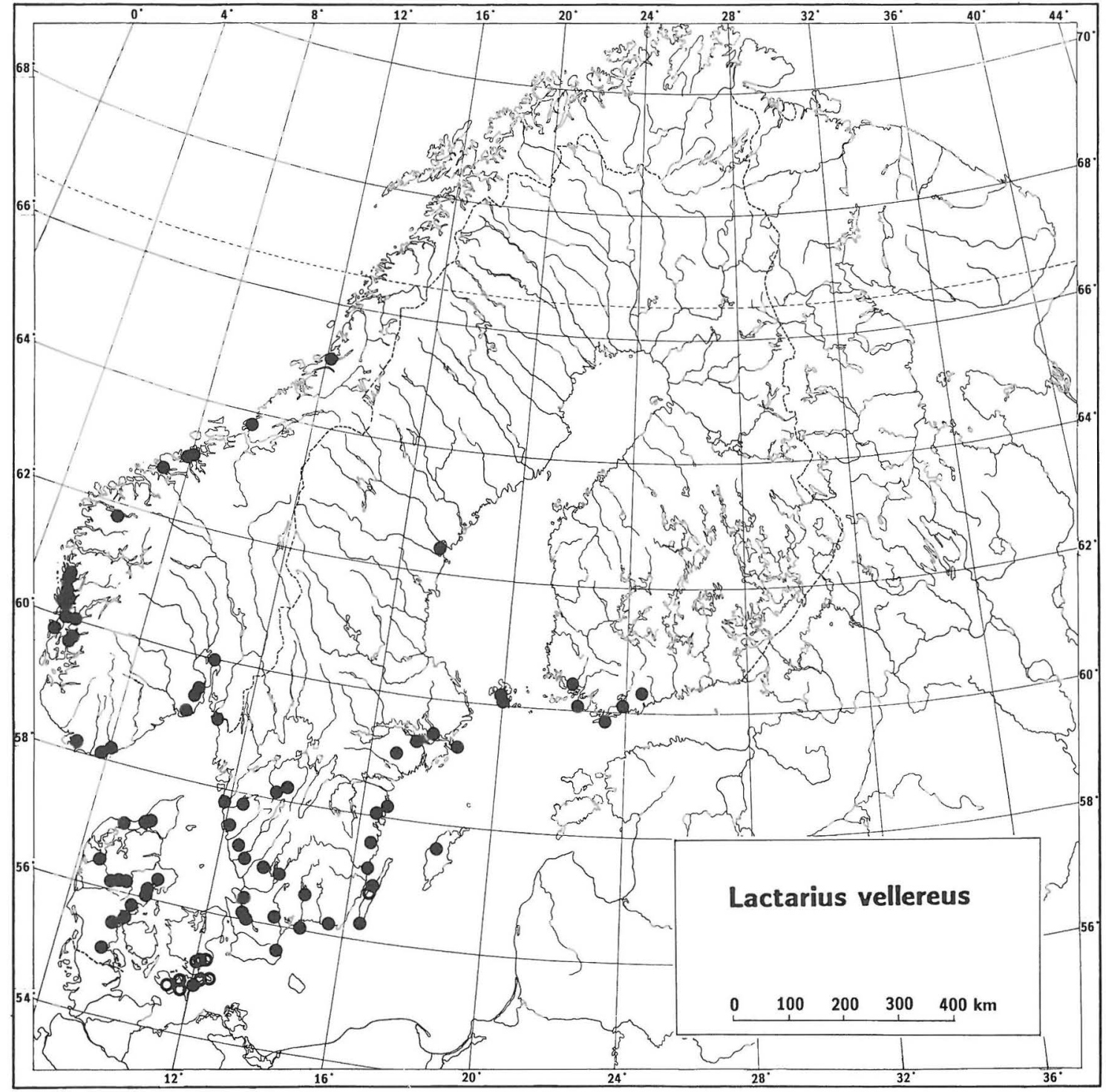

Fig. 1. Distribution of Lactarius vellereus in Fennoscandia and Denmark according to the specimens examined (dots) and the field observations of the authors (circles).

The species is not exacting as regards the nutrient contents of the soil. The characteristic habitats are fairly rich in herbs with a poorly developed and discontinuous moss layer. The distribution corresponds rather well to the vegetation zones (cf. Ahti et al. 1968), and the northern limit is not correlated with that of any of the mycorrhizal partners.

Outside Fennoscandia $L$. vellereus is one of the most common Lactarius species in the temperate zone in lowlands in Europe (Neuhoff 1956, Pilát \& Ušák 1961, Phillips 1981, Krieglsteiner 1984, Bon 1980b,
1987, Kreisel 1987). In North America its occurrence is doubtful (cf. Hesler \& Smith 1979). The species has not always been correctly separated from $L$. bertillonii, but apparently at least most of the reports of the above authors are best referred to $L$. vellereus $\mathrm{s}$. str. In Pilát \& Ušák (1961) most of the description conforms with $L$. vellereus s.str., but some characters, e.g. the acrid latex and the early termination of fruit body production (cf. below), belong to $L$. bertillonii.

In Fennoscandia $L$. vellereus produces basidiocarps fairly late in the autumn (Fig. 5). The earliest 


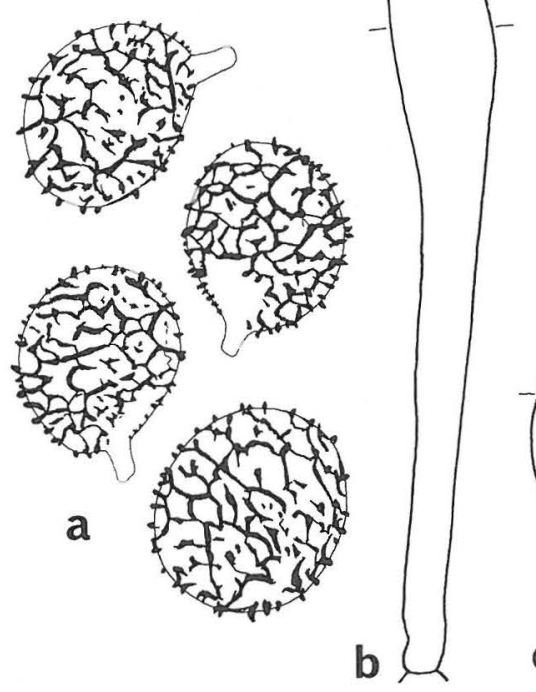

\section{$10 \mu \mathrm{m}$}
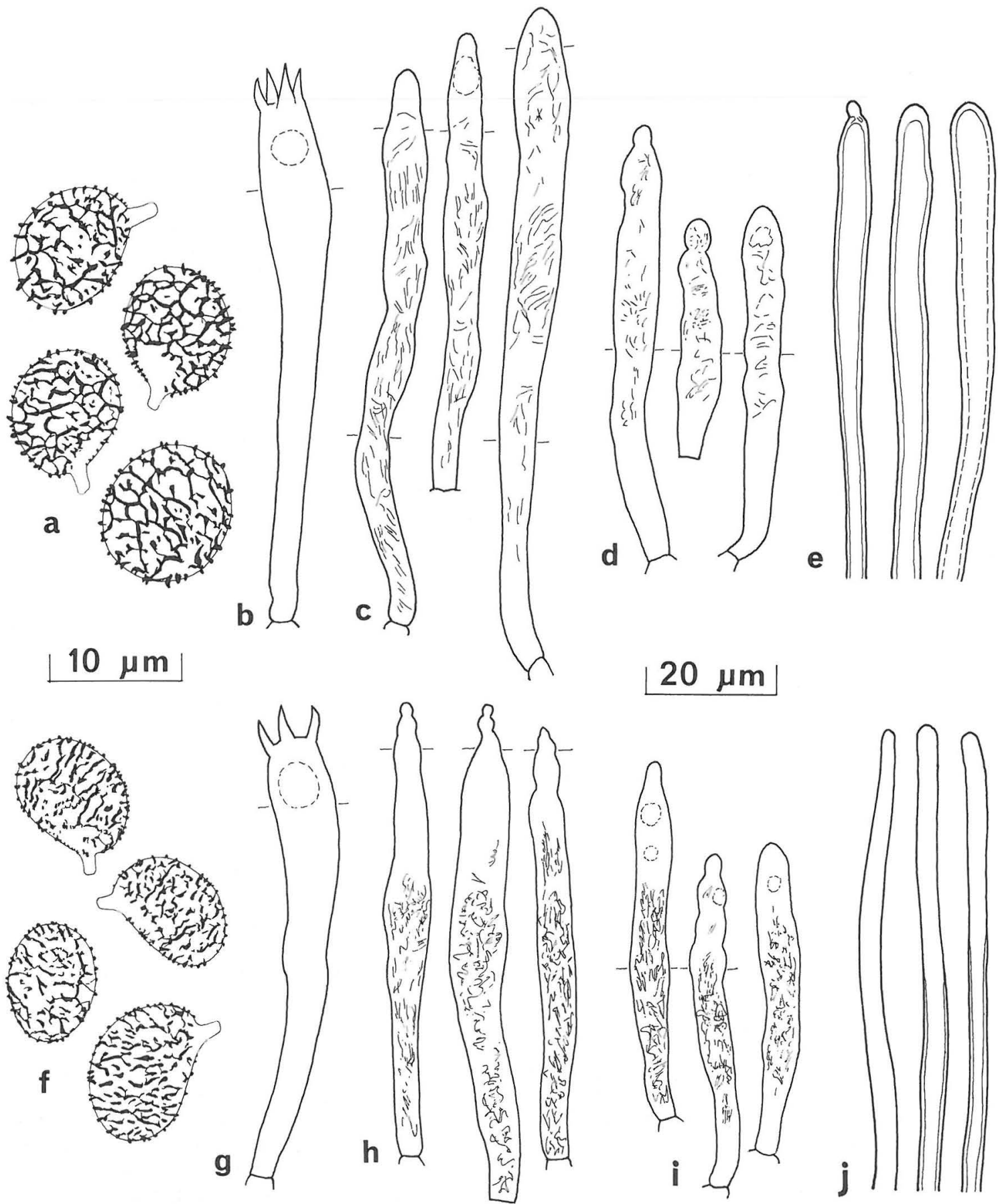

Fig. 2. Microscopic details. Lactarius vellereus: a. Spores (Sweden, Västergötland, Varv, Kytövuori 84622). b. Basidia. c. Macrocystidia. d. Cheilocystidia. (b-d Sweden, Småland, Angelstad, Kytövuori 88-1985). e. Tips of pileal hairs, (Sweden, Blekinge, Mjällby, Kytövuori 851244). L. bertillonii: f. Spores (Finland, Uusimaa, Kirkkonummi, Kytövuori 84483). g. Basidia. h. Macrocystidia. i. Cheilocystidia. (g-i Finland, Varsinais-Suomi, Halikko, Kytövuori 88-1616). j. Tips of pileal hairs (Sweden, Blekinge, Mjällby, Kytövuori 851245, all in H). Spores x 2000 , others x 1000. 
specimens have been collected at the end of August and the latest in November. The species seems to be nearly one month later than $L$. bertillonii. In the Czechoslovakian material in PRM (25 collections) the difference in the phenology is also evident. The late fruit body production of $L$. vellereus may be a factor limiting the distribution of the species in the north.

\section{Discussion}

The interpretation of the name Lactarius vellereus is confusing. Many authors have approached the question solely from the nomenclatural point of view and neglected to go deeper into the morphological variation and the distribution of the complex. Considerable attention has been paid to the variation in the taste, to the colour change and some other chemical reactions of the latex and to the density of the lamellae, but no revision of larger material exists. Of the commonly used characters, the density of the lamellae is, on the whole, the only one which can be used in dried material. Strid (1987) knew only one taxon in Sweden, which had acrid latex, and he considered the existence of a taxon with mild latex doubtful, while Krieglsteiner (1984) and Kreisel (1987) in Germany emphasized the mildness of the latex. Schaefer (1979) recognized some heterogeneity in $L$. vellereus, but he seems to have been confused by the abundance of the earlier described variants.

In France Romagnesi (1980) reported three species of the $L$. vellereus complex but interpreted the acridmilked species as $L$. vellereus s.str. Bon (1980b) accepted Neuhoff's (1956) treatment and divided the present complex into two groups: the stirps Vellereus, containing $L$. vellereus s.lat. and $L$. albivellus Romagnesi with subglobose, reticulate spores and unchanging latex, and the stirps Bertillonii with narrower and non-reticulate spores and latex turning yellow. Besides $L$. bertillonii, he included in the latter group $L$. moravicus Z. Schaefer, described from Czechoslovakia, and the American L. subvellereus Peck. In North America Hesler \& Smith (1979) have divided the complex in the same manner.

In Fennoscandia also the material of the complex can easily be divided into two. The one group is characterized by mild latex (when separate from the flesh), long and thick hairs on the pileus and stipe and large, subglobose, \pm reticulate spores, while the other has strongly acrid latex, shorter and thinner hairs on the pileus and stipe, and ellipsoid to broadly ellipsoid, finely ornamented but not reticulate spores. In spite of some variation in the characters, the specimens can always be identified as one or other of the two taxa,

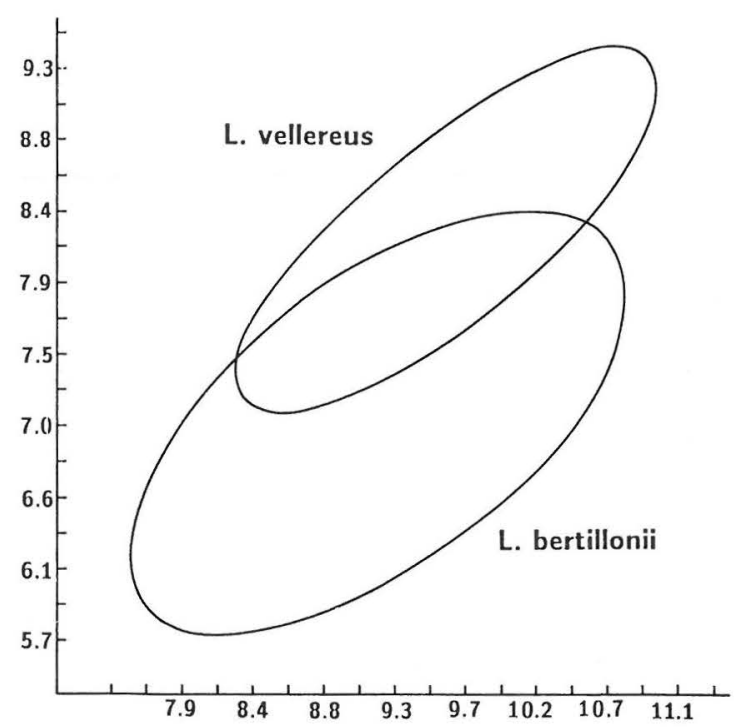

Fig. 3. Diagram showing the spore size of Lactarius vellereus and $L$. bertillonii. The lines are drawn on the basis of scatter diagrams, and represent $95 \%$ of the spores measured on each species (L. vellereus 263 spores, 14 specimens, L. bertillonii 354 spores, 18 specimens). $x$ axis: length of spores. $y$ axis: width of spores.

and no intermediate forms exist. The determination is best done by comparing pieces of gills or hairs from different specimens mounted side by side on the same slides. With young basidiocarps only hairs can be used. The hairiness can also successfully be compared by checking different basidiocarps side by side under a dissecting microscope. In the field in dry weather, or in old basidiocarps in general, the latex may be scanty and may be difficult to separate from the flesh for tasting, which easily causes confusion in the identification, if other characters are not used.

The differences between the two taxa mentioned above are so numerous that they can certainly be separated at the specific level. The problem is to which of them the name $L$. vellereus belongs.

When Fries (1821) published his Systema plantarum, he was living at Femsjö in southwesternmost Småland in South Sweden and had been a student at Lund in Skåne. In Skåne the mild-milked species is much commoner than the other one. In the Femsjö region both species exist. We have visited Femsjö only once (in September 1987), and then the mushroom season was very poor and only two very scanty occurrences of the acrid-milked species were seen. But all the 5 specimens from Femsjö existing in the Swedish herbaria represent the mild-milked species. One of them is the large exsiccata specimen 2334 of 


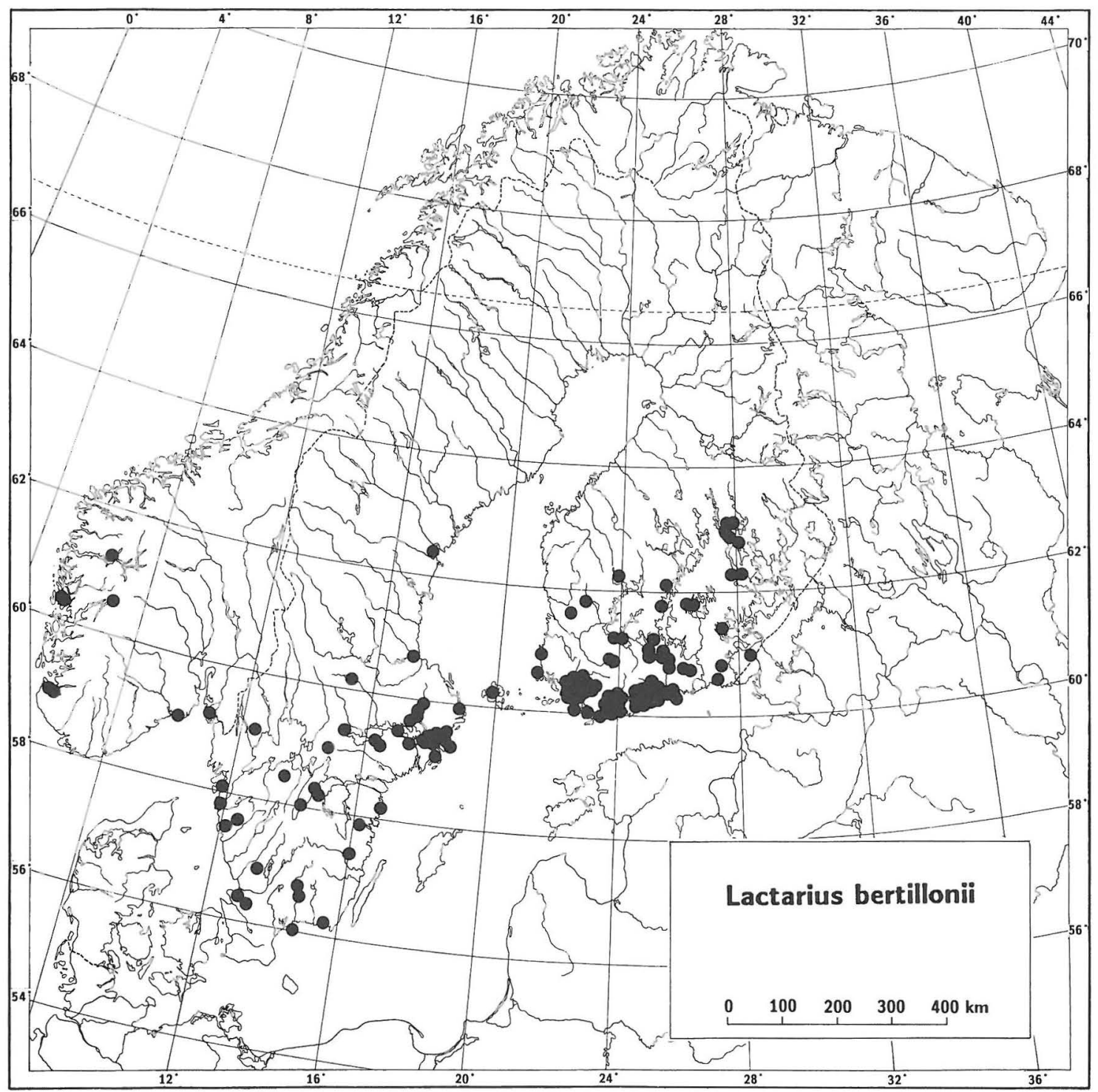

Fig. 4. Distribution of Lactarius bertillonii in Fennoscandia and Denmark according to the specimens examined.

Lundell (in many herbaria), which according to the label was collected "along the ancient road from Prästgårdens såg", and thus evidently included material from a fairly large area. In 1988 Kytövuori searched for the group in the country around Femsjö. Four occurrences (all mild-milked) were found: at Rolfstorp, Vessige and Torup in Halland W of Femsjö and at Angelstad in Småland E of Femsjö. These observations indicate that the mild-milked species is the commonest of the two in Femsjö.
Fries (1821) said nothing of the taste of $L$. vellereus, but his note on the ecology "In Fagetis, dumetis, etc. abunde" supports Neuhoff's (1956) conclusion that the mild-milked species should be considered to be L. vellereus (Fr.: Fr.) Fr. Later Fries (1838) reported that the latex of $L$. vellereus was acrid, but then he was living in Uppsala, where the acrid-milked species is apparently the only one of the group.

The specimen of Lundell, Fungi Exs. Suec. Ups. 2334 from Femsjö (UPS, Lundell \& Nannfeldt 1956) 
is therefore here selected as the neotype of $L$. vellereus (Fr.: Fr.) Fr.

\section{Specimens examined}

The delimitation and order of the biological provinces are according to the forthcoming "Flora Nordica".

Finland. Ahvenanmaa (Aland): Jomala, Jättböle, 1978 Ulvinen (OULU), Lemland, Nåto, 1980 Korhonen 3574 \& Tuomikoski (2 ex. H). Varsinais-Suomi: Turku, Ruissalo, 1988 Ruotsalainen et al. (H, KUO, TUR), Văstanfjärd, Grundsund, 1961 Malmström (H). Uusimaa: Espoo, Nuuksio, 1972 Federley (H), Inkoo, Fagervik, 1854 Hisinger $(\mathrm{H})$, Tammisaari, Tvărminneön, 1937 Malmström $(\mathrm{H})$.

Sweden. Skåne: Knislinge (H), Riseberga (3 ex. H), Rörum $(\mathrm{H})$, Stenestad $(\mathrm{H})$, Tosjo (H). Blekinge: Förkärla (4 ex. H, UPS), Mjällby (H). Öland: Ås (S), Borgholm (H, UPS), Hogsrum (Kytövuori, no specimen). Gotland: Bro (UPS). Östra Småland: Misterhult (H), Mönsterås (H), V. Ed (H). Inre Småland: Angel$\operatorname{stad}(\mathrm{H})$, Femsjö (C, GB, PRM, 4 ex. UPS), Urshult (H). Halland: Fjärås (GB), Rolfstorp $(\mathrm{H})$, Torup $(\mathrm{H})$, Vessige $(\mathrm{H})$. Göteborg \& Bohuslän: Göteborg (4 ex. GB). Västergötland: Floby (S), Varv (H), Skallsjo (GB). Östergötland: Gryt (2 ex. UPS). Södermanland: Hyltinge (S), Overenhörna (S). Uppland: Djurö (3 ex. S), Järfălla (OULU). Medelpad: Sundsvall, Stadsberget, 1984 Muskos 4091 (UPS, Eriksson et al. 1985:214).

Norway. Østfold: Hvaler (O). Akershus og Oslo: Oslo (O). Vestfold: Larvik (O), Ramnes (O). Vest-Agder: Lyngdal (O), Oddernes (O), Søgne (O). Hordaland: Bergen (3 ex. BG), Bømlo (BG), Etne (BG), Fana (2 ex. BG), Kvinnherad (BG), Lindås (2 ex. BG), Os (BG), Tysnes (BG). Sogn og Fjordane: Sandane (BG). Mфre og Romsdal: Molde (BG), Tingvoll (2 ex. TRH). Sør-Trøndelag: Bjugn, Koet, 1984 Sivertsen (TRH). Sør-Nordland: Bindal, Årsandöy, 1969 Stordal 13007 (O).

Denmark. Nordjylland: Åbybro (2 ex. C), Østerild (C), Strøsøpet (C). Østjylland: Boller (UPS), Fløistrup (2 ex. C),
Kolding (C), Rønde (OULU), Silkeborg (3 ex. C), Trelde Nøs (2 ex. C). Sydjylland: Åbenrå (H), Haderslev (3 ex. H). Sjalland \& surrounding islands: Sjælland: Leestrup, Store Elmue, Vemmetofte (Korhonen, no specimen), Lolland: Frejlev, Hørjeby, Nyköping (Korhonen, no specimen), Falster: Stubbekőbing (C). Møn: Fanefjord, Møns Klint (Korhonen, no specimen).

\section{Lactarius bertillonii (Neuh. ex Z. Schaefer)} M. Bon, Figs. 2-5.

Lactarius bertillonii (Neuh. ex Z. Schaefer) M. Bon, Doc. Mycol. 10(37-38): 92. 1980. - Lactarius vellereus var. bertillonii Neuh., Milchlinge 93. 1956. Nom. inval. - Lactarius vellereus var. bertillonii Neuhoff ex Z. Schaefer, Ceská Mykol. 33:9. 1979. - Holotype: Czechoslovakia, Bohemia centralis, Golcuv Jeníkov, silva mixta, Picea, Pinus, Abies, Betula, Quercus, 22.VII.1949 Schaefer (Herb. Schaefer St. 41). Not seen.

Illustrations: Bresadola (1928: 372, s.n. L. vellereus, most probably), Korhonen (1984: 67, 1986: 83), Marchand (1980: 17), Ryman \& Holmåsen (1984: 555, s.n. L. vellereus, most probably).

Large and robust, often anomalous in form. Pileus 10-20(-25) cm wide, convex-depressed to plano-depressed, with margin inrolled when young, slowly outrolling with age, dry, covered by woolly hairs throughout. The hairs shorter, somewhat more curled and less tangled into acute tufts than in L. vellereus, present in the oldest basidiocarps as well. Colour uniformly pure white to pale ochraceous, white or pale ochraceous also in dried basidiocarps. Context thick (10-20 mm at broadest point of lamellae) and firm, burningly acrid, with only faint, somewhat sweetish odour. Latex white, very slowly changing to yellow-

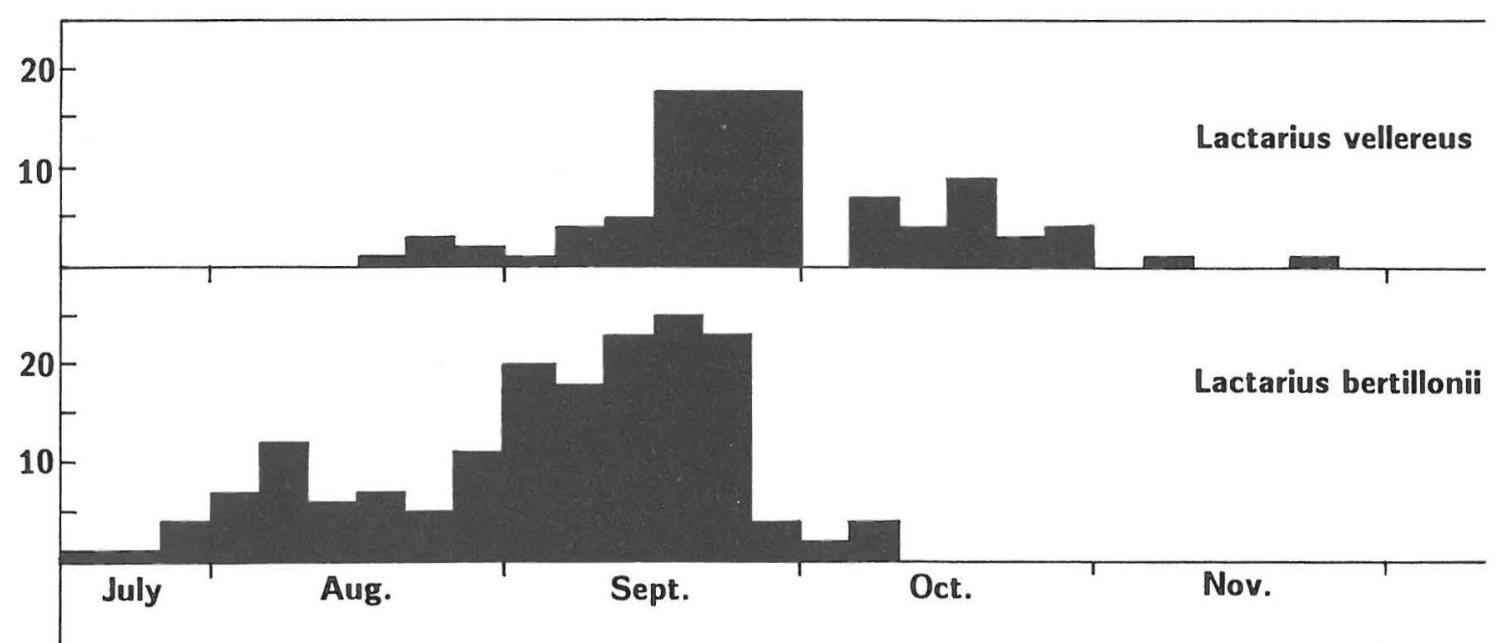

Fig. 5. Fruiting periods of Lactarius vellereus and $L$. bertillonii according to the material examined. $x$ axis: the period from 16 .VII to 24.XI divided into pentads. y axis: number of specimens collected (or field observations made by the authors) in each pentad. 
ish, with $\mathrm{KOH}$ at first yellow, soon orange (cf. e.g. Bellù 1989), very strongly acrid even when separated from the flesh.

Lamellae adnate, moderately narrow, thick (3-6 $(-8) \mathrm{mm}$ at broadest point, context $2-5$ times as thick at the same point), distant, straight or somewhat flexuose near the stipe, often forked and anastomosing, whitish, lamellulae numerous.

Stipe robust, often somewhat eccentric, $3-8 \mathrm{~cm}$ long, $2-6 \mathrm{~cm}$ thick, most often relatively larger than in L. vellereus, hard, solid, most often tapering downwards, dry, hirsute like the pileus, but the hairs still less tangled into tufts than in $L$. vellereus.

Spores $7.9-10.7 \times 5.7-8.2 \mu \mathrm{m}$ (354 spores from 18 ex.), length/width ratio $1.17-1.50$, ellipsoid to broadly ellipsoid, with amyloid ornamentation of very minute elongated warts and tortuous lines, not forming even a broken reticulum, less than $0.2 \mu \mathrm{m}$ high, plage \pm inamyloid (Figs. 2, 3).

Basidia 57-73 x 8-11 $\mu \mathrm{m}$ ( 60 bas. from 6 ex.), 4-spored. Macrocystidia abundant, 50-90(-120) x 5-8 $\mu \mathrm{m}$ (130 cyst. from 7 ex.), lanceolate to narrowly clavate with obtuse apex when young, more pointed with age, imbedded or slightly (up to $25 \mu \mathrm{m}$ ) projecting, with the broadest point in the hymenium, sometimes originating very deep in the trama, altogether more pointed than in $L$. vellereus. Cheilocystidia abundant, similar to the macrocystidia but smaller, 35-70 × 5-8 $\mu \mathrm{m}$ (139 cyst. from 7 ex.), and more $(10-35 \mu \mathrm{m})$ projecting. Differentiated pseudocystidia not seen.

Pileal hairs long but shorter and more curled than in L. vellereus, thick-walled, at the tip 1.8-3.6 $\mu \mathrm{m}$ thick (208 hairs from 15 ex.), about twice as thick at the base. Cauline hairs similar but somewhat straighter.

\section{Distribution and ecology}

Lactarius bertillonii is the commonest species of the present group in Fennoscandia. It is common in the hemiboreal zone near the southern coast of Finland and in the southern part of Sweden south of Uppland (Fig. 4). In the temperate zone, in Skåne, Halland and southernmost Blekinge, it is rarer and markedly less common than $L$. vellereus. In Denmark the species is not yet known, but it will probably be found there, as the nearest occurrences in Skåne in Sweden are so close.

In the southern boreal zone it is common in the southern part but rapidly becomes rarer farther north and is unlikely to exceed the northern limit of that zone. Thus the distribution of the species is unusually narrow in the south-north direction. According to the specimens in the Norwegian public herbaria, the species is fairly rare in both the Oslo region and Vestlandet in Norway. The distribution corresponds well to the vegetation limits of the southern boreal and hemiboreal zones (cf. Ahti et al. 1968), though its mycorrhizal hosts have quite different distribution limits.

The species grows in frondose broad-leaved or mixed woods. It is unlikely to occur in pure coniferous woods in Fennoscandia, but often only a few broad-leaved trees are present in its habitats. It is not dependent on any specific tree species. Basidiocarps are found not only in pure Fagus or Quercus woods or around solitary Quercus trees, but also in Betula forests or conifer forests mixed with Betula. Farther north Betula becomes the most important mycorrhizal host. $L$. bertillonii never seems to be as abundant in its habitats as $L$. vellereus may be. Most often the habitats are half-open, and fairly rich in herbs and the moss layer is discontinuous or poorly developed. Slight grazing by cattle or sheep or cutting or trampling of the vegetation favours the species, or at least its basidiocarp production.

In Fagus-Quercus woods at least, $L$. bertillonii may occur together with $L$. vellereus, but we have not yet seen real mixed stands.

The distribution of the species outside Fennoscandia is difficult to outline, as $L$. bertillonii is commonly overlooked in the mycological literature. Neuhoff (1956) saw only a few specimens of the species and Schaefer (1979) considered it to be rare, but clearly did not know it very well. In France the presence of $L$. bertillonii has been reported, but only very scanty information on its distribution or abundance is given, e.g. by Bon (1980b), Marchand (1980) and Romagnesi (1980). Bon (1987) causes further complications when he says of $L$. bertillonii: "taste only slightly acrid", a very surprising comment on the species which in Fennoscandia is most acrid. Phillips (1981) reports $L$. vellereus var. bertillonii from the British Isles and his notes on the phenology of $L$. vellereus $\mathrm{s}$. lat. confirm the occurrence of $L$. bertillonii there, but no detailed reports exist. According to the specimens in PRM (9 ex. L. vellereus, 12 ex. L. bertillonii) and $\mathrm{S}$ (4 ex. L. vellereus, 5 ex. L. bertillonii), the species seems to be not infrequent in Czechoslovakia and in uplands in and round the Alps. The description of $L$. vellereus in Bresadola (1928) also fits $L$. bertillonii well. Urbonas et al. (1986) report only L bertillonii from the Baltic countries of the U.S.S.R. More extensive studies on larger material will presumably show that $L$. vellereus occurs there as well.

In Fennoscandia $L$. bertillonii produces basidiocarps early in the autumn (Fig. 5). The earliest specimens have been collected in the middle of July and the 
latest at the beginning of October. The species seems to be nearly one month earlier than $L$. vellereus. This difference in phenology is also apparent in the material of PRM (25 specimens).

\section{Discussion}

Lactarius bertillonii is easily distinguished from $L$. vellereus by the strongly acrid latex (also when separate from the flesh), shorter and thinner hairs on the pileus and stipe and ellipsoid to broadly ellipsoid, finely ornamented but not reticulate spores. However, in the field care must be taken if the latex is scanty. We have both sometimes made mistakes in our provisional field identifications.

At the specific level, the name $L$. bertillonii dates back only to Bon (1980a). However, few older specific names exist that need be taken into account in clarifying the nomenclature of the taxon. In North America L. subvellereus Peck, Bull. Torrey Bot. Club 25:369. 1898 var. subdistans Hesler \& A.H. Smith, N. Amer. Lactarius: 203. 1979 seems to be very close to the European $L$. bertillonii. We have not seen the type, but according to the specimens from Canada, Québec, Gatineau Park, 1987 M. Aalto (H) and U.S.A., Vermont, 1906 G.S. Burlingham, Lact. N. Amer. no. 3 (S, also cited by Hesler \& Smith 1979), some differences exist, e.g. very copious latex and slightly thicker and longer hairs. More material is needed to decide the identity of that species. Another problem is whether the more southern $L$. subvellereus var. subvellereus is different from var. subdistans A.H. Smith at the specific level .

Hesler \& Smith (1979) misinterpreted Neuhoff's var. bertillonii. When Neuhoff (1956) described $L$. vellereus var. bertillonii, he named the variety in honour of Bertillon, who was "der erste ... der zwei verschiedene Typen in dieser Gruppe unterschied", but not as a synonym of $L$. velutinus Bertillon.

In Europe L. moravicus Z. Schaefer, Česká Mykol. 33:10. 1979 has been placed near $L$. bertillonii by Bon (1980b). Schaefer (1979) considered the species very close to L. vellereus s.lat., but did not compare it with var. bertillonii. He said nothing of the taste of the latex and the description includes some characters, such as the greening context and the close lamellae, that do not fit at all with those of $L$. bertillonii. We have seen no material of $L$. moravicus. Z. Schaefer's material is not available in the public herbaria.

L. bertillonii is clearly a distinctive species and definitely different from $L$. vellereus, but more material and work is needed to clear up the other taxa possibly existing in the $L$. vellereus group.

\section{Specimens examined}

U.S.S.R. Karelian A.S.S.R. Vyborg, 1892 Thesleff (H).

Finland. Ahvenanmaa (Åland): Finström (TUR). VarsinaisSuomi: Bromarv (4 ex. H), Halikko (2 ex H, TUR), Karjaa (H), Karjalohja (H, OULU), Kemio (H, OULU, TUR), Kustavi (H), Lemu (TUR), Lohja rural commune (2 ex. H), Lokalahti (TUR), Mietoinen (TUR), Mynămäki (TUR), Parainen (4 ex. TUR), Piikkiö (TUR), Pohja ( 2 ex H), Turku ( 2 ex. H, 14 ex. TUR), Uusikaupunki rural commune (OULU, TUR), Văstanfjărd (H). Uusimaa: Artjärvi (2 ex. H), Elimäki (H), Espoo (4 ex. H), Helsinki (H), Jărvenpă (2 ex. H), Inkoo (2 ex. H), Kauniainen (4 ex. H), Kirkkonummi (3 ex. H), Nurmijärvi (3 ex H), Porvoo rural commune (4 ex. H), Sipoo (5 ex. H), Tammisaari (H), Tuusula (2 ex. H), Vantaa (4 ex. H). Etelä-Karjala: Joutseno (2 ex. H), Vehkalahti (2 ex. H), Virolahti (H). Satakunta: Jămijärvi (H), Kullaa (TUR), Etelä-Häme: Jämsă (TUR), Joutsa (KUO), Lahti (3 ex. H), Lammi (4 ex. H), Lempäälä (H), Tammela (2 ex. H, KUO), Virrat (H). Pohjois-Häme: Jyväskylä (JYV, Saari \& Ohenoja 1988). Pohjois-Savo: Joroinen (H), Kangaslampi (H), Kuopio (3 ex. KUO), Ristiina (H), Siilinjärvi (2 ex. KUO), Vehmersalmi (H, KUO).

Sweden. Skåne: Örkeljunga $(\mathrm{H})$. Blekinge: Mjällby $(\mathrm{H})$, Nättraby (H). Östra Småland: Hallingeberg (UPS), Kvistdala (UPS). Inre Småland: Femsjö (2 ex. H), Skatelöv/ V. Torsås (H), Urshult (H), Visingð (UPS). Halland: Fjărås (GB), Ǒ. Karup (H). Göteborg \& Bohuslän: Göteborg (2 ex. GB), Ödsmål (GB). Västergötland: Säter (H), Sätila (GB). Östergötland: Alvastra (H), Gryt (UPS), Sättra (H). Närke: Hovsta (UPS), Viby (H). Södermanland: Aspő (H), Flen (H), Nacka (S), Näshulta (H), Österhaninge (S), Overenhörna (S), Stockholm (S). Uppland: Börje (2 ex. UPS), Djursholm (S), Djurő (S), Häggeby $(\mathrm{H})$, Husby-Sjutolft (H), Lena (UPS), Lővö (2 ex. UPS), Ö. Ryd (S). Österåker (S). Roslags-Kulla (H, S), Solna (2 ex. S), Stockholm (S), Väddö $(\mathrm{H})$, Dalarna: Ludvika $(\mathrm{H})$. Gästrikland: Gävle (UPS).

Norway. Østfold: Kråkerøy (O). Vestfold: Brunlanes (O). Rogaland: Sandnes (BG, O). Hordaland: Fana (BG, O), Ulvik (BG). Sogn og Fjordane: Balestrand (BG).

Acknowledgements. We thank Prof. Teuvo Ahti, for valuable suggestions regarding the manuscript. We are also indebted to Dr. Harri Harmaja and Mr. Roland Skytén, M.Phil, for arranging the loans, to Mrs. Siv Muskos and Mr. Jan Vesterholt for sending some material, to Dr. Marjatta Aalto for a Canadian specimen of Lactarius subvellereus, and to Mrs. Anna Damström, M.A., for the English revision.

\section{References}

Ahti, T. 1976: Rouskut - Lactarius. - In: Ulvinen, T. (ed.), Suursieniopas: 191-200. Helsinki.

Ahti, T., Hämet-A hti, L. \& Jalas, J. 1968: Vegetation zones and their sections in northwestern Europe. - Ann. Bot. Fennici 5:169-211.

Bellù, F. 1989: Primi passi: Le principali reazioni chimiche nei funghi ed il loro uso determinativo. - Riv. Mic. Boll. Ass. Micol. Bresadola 32:230-234.

Blum, J. 1966: Lactaires et Russules au salon du champignon de 1965. - Rev. Mycol. 31:85-106. 
Bon, M. 1980(1979)a: Novitates: Taxons nouveaux. — Docum. Mycol. 10(37-38): 89-92.

Bon, M. 1980b: Clé monographique du genre Lactarius (Pers. ex Fr.) S.F. Gray. - Docum. Mycol. 10(40): 1-85.

Bon, M. 1987: The mushrooms and toadstools of Britain and North-Western Europe. - 352 pp. London.

Bresadola, J. 1928: Iconographia mycologica 8. - Pls. 351-400. Mediolani.

Dähncke, R.M. \& Dähncke, S.M. 1980: 700 Pilze in Farbfotos. Ed. 2. - 686 pp. Stuttgart.

Eriksson, C., Lidberg, R., Lindström, H., Muskos, S., Tedebrand, J.O. \& Wimo, J.O. 1985: Medelpads svampar. En sammanfattning av vår nuvarande kunskap om svamparnas förekomst och utbredning i landskapet. - 239 pp. Sundsvall.

Fries, E. 1821: Systema mycologicum 1. $-57+520$ pp. Lundae.

Fries, E. 1838: Epicrisis systematicis mycologici. $-12+610$ pp. Upsaliae.

Hesler, L.R. \& Smith, A.H. 1979: North American species of Lactarius. - 841 pp. Ann Arbor.

Holmgren, P.K., Keuken, W. \& Schofield, E.K. 1981: Index herbariorum 1. The herbaria of the world. Ed. 7. - Regnum Vegetabile 106:1-452.

Korhonen, M. 1984: Suomen rouskut. -223 pp. Helsinki.

Korhonen, M. 1986: Uusi sienikirja. - 318 pp. Helsinki.

Korhonen, M. \& Kytövuori, I. 1987: Två arter av luden vitriska i Norden - Lactarius vellereus (Fr.) Fr. och L. bertillonii (Neuh. ex Z. Schaefer) M. Bon. - Jordstjäman $8: 45-48$.

Kreisel, H. (ed.) 1987: Pilzflora der Deutschen Demokratischen Republik. Basidiomycetes (Gallert-, Hut- und Bauchpilze). - 281 pp. Jena.

Krieglsteiner, G.J. 1984: Verbreitung und Ökologie 250 ausgewăhlter Blätter- und Röhrenpilze in der Bundesrepublik Deutschland (Mitteleuropa). - Zeitschr. Mykol. Beih. 5:69-302.
Lundell, S. \& Nannfeldt, J.A. 1956: Fungi exsiccati suecici, praesertim upsalienses. Fasc. 47-48. Nos. 2301-2400. - 50 pp. Uppsala.

Marchand, A. 1980: Champignons du Nord et du Midi 6. Lactaires et Pholiotes. - 291 pp. Perpignan.

Michael, E., Henning, B. \& Kreisel, H. 1983: Handbuch für Pilzfreunde 5. Ed. 3. - 408 pp. Stuttgart.

Moser, M. 1983: Die Rőhrlinge und Blätterpilze. — In: Gams, H.: Kleine Kryptogamenflora IIb/2.2. Ed. 5. 8+533 pp. Stuttgart.

Neuhoff, W. 1956: Die Milchlinge (Lactarii). - Die Pilze Mitteleuropas IIb: 1-248, 18 pls. Bad Heilbrunn Obb.

Phillips, R. 1981: Mushrooms and other fungi of Great Britain and Europe. $-288 \mathrm{pp}$. London.

Pilát, A. \& Ułák, O. 1961: Mushrooms and other fungi. - 160 pls. London.

Romagnesi, H. 1980: Nouvelles observations sur les Lactaires blancs (Albati Bataille). - Bull. Soc. Mycol. France 96:73-95.

Ryman, S. \& Holmåsen, I. 1984: Svampar. En fälthandbok. 718 pp. Stockholm.

Saari, V. \& Ohenoja, E. 1988: A check-list of the larger fungi of Central Finland. - Biol. Res. Rep. Univ. Jyväskylä 11:3-74.

Schaefer, Z. 1979: Beitrag zum Studium der Sektion Albates der Lactarien. - Ceská Mykol. 33:1-12.

Strid, ̊. 1987: Vitriskomas taxonomi - historik och synpunkter. Med en presentation av arterna i stockholmstrakten. - Jordstjärnan 8:5-23.

Urbonas, V., Kalamees, K. \& Lukin, V. 1986: Conspectus florum agaricalium fungorum (Agaricales s.l.) Lithuaniae, Latviae et Estoniae. - 139 pp. Vilnius.

Viola, S. 1977: Die Pilze. Ed. 2. - 112 pls. München.

Received on 27 February 1990 